\title{
Nocardia farcinica lung infection in a patient with cystic fibrosis: a case report
}

\author{
Fadi Bittar ${ }^{1}$, Nathalie Stremler ${ }^{2}$, Jean-Pierre Audié ${ }^{3}$, Jean-Christophe Dubus ${ }^{2}$, Jacques Sarles ${ }^{2}$, Didier Raoult ${ }^{1}$, \\ Jean-Marc Rolain ${ }^{1 *}$
}

\begin{abstract}
Introduction: Respiratory tract infections are the major causes of morbidity and mortality in patients with cystic fibrosis. Nocardia are rarely implicated in these infections and few reports of the involvement of this species are found in the literature.
\end{abstract}

Case presentation: We describe a case of lung infection followed by chronic colonization of trimethoprim and sulfamethoxazole resistant Nocardia farcinica in a patient with cystic fibrosis. The chronic colonization of this uncommon bacterium in patients with cystic fibrosis was proved using a newly developed real-time polymerase chain reaction assay, which indicates that this bacterium, despite treatment, is difficult to eradicate.

Conclusion: Our case report confirms that this organism can be recovered in persons with cystic fibrosis. Its eradication is necessary especially if the patient is to undergo lung transplantation.

\section{Introduction}

Since the early description of cystic fibrosis (CF), pulmonary infection has been recognized as having the greatest role in morbidity and mortality leading to premature death in $90 \%$ of patients reported $[1,2]$. It has been demonstrated that accurate antimicrobial treatment is of great importance in avoiding the rapid destruction of the lung function of patients and in the spread of multidrug-resistant and/or highly virulent pathogens [1].

\section{Case presentation}

In February 2007, a 15-year-old Caucasian French boy with $\mathrm{CF}(\Delta \mathrm{F} 508$, M1V heterozygote genotyping pattern) was admitted to the CF center in Marseille, France. He presented with fever $\left(39^{\circ} \mathrm{C}\right)$, fatigue, haemoptysis, bronchial syndrome, and respiratory decompensation. His chest X-ray showed multiple bilateral bronchial thickening. He has had a history of persistent colonization of the respiratory tract since childhood with Staphylococcus aureus and Haemophilus influenzae. He also had a primary

\footnotetext{
* Correspondence: jean-marc.rolain@univmed.fr

'Unité de Recherche sur les Maladies Infectieuses et Tropicales Emergentes (URMITE), CNRS-IRD, UMR 6236, Faculté de Médecine et de Pharmacie, Université de la Méditerranée, Boulevard Jean Moulin, 13385 Marseille cedex 5, France
}

(c) 2010 Bittar et al; licensee BioMed Central Ltd. This is an Open Access article distributed under the terms of the Creative Commons Attribution License (http://creativecommons.org/licenses/by/2.0), which permits unrestricted use, distribution, and reproduction in any medium, provided the original work is properly cited.

colonization with Pseudomonas aeruginosa at the age of 10 and with Aspergillus fumigatus and Candida albicans at the age of 13. Our patient received inhaled fluticasone $(1500 \mu \mathrm{g} /$ day $)$ on several occasions in 2006.

On admission, his laboratory tests showed a white blood cell count of $25.63 \times 10^{9} / \mathrm{L}$ with $87 \%$ polymorphonuclear cells (PMNs). His C-reactive protein (CRP) was at $92 \mathrm{mg} / \mathrm{L}$. A direct Gram-staining of his sputum taken at the time of his admission showed the presence of many polymorphonuclear leukocytes without squamous cells. The presence of Gram-positive branching filamentous bacilli and Gram-positive cocci was also noted. A standard culture and conventional identification of his sputum sample yielded $10^{4} \mathrm{CFU} / \mathrm{ml}$ of $S$. aureus, $10^{4} \mathrm{CFU} / \mathrm{ml}$ of Nocardia sp. that was isolated from Columbia colistin-nalidixic acid (CNA) agar (BioMérieux, Marcy l'Etoile, France) after three days of incubation. Accurate identification at species level was achieved after $16 \mathrm{~S}$ rDNA amplification and sequencing [3] leading to the discovery of $N$. farcinica (GenBank accession number AB162795, 100\%). The sequence of our isolate has been deposited in GenBank under accession number EU861514. The phylogenetic position of N. farcinica (strain 7400458) among closely related bacteria is presented in Figure 1. Using the disk diffusion method we found out that the isolate was resistant to 


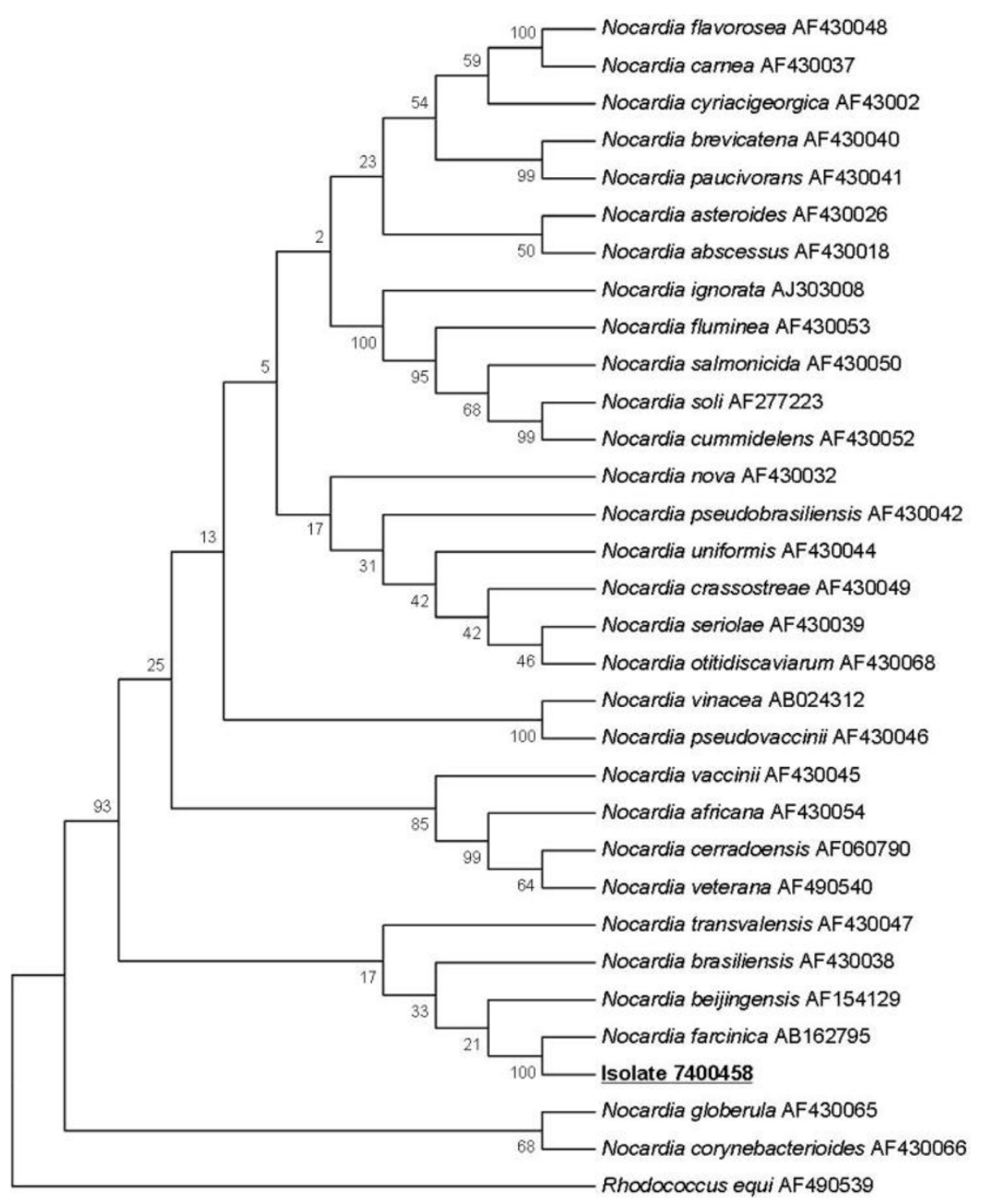

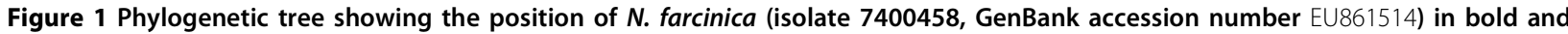
underlined within other Nocardia species. The tree was based on $16 \mathrm{~S}$ rDNA comparison (1441 bp) using the neighbor-joining method from MEGA 4.0 software.

rifampicin, erythromycin, gentamycin, doxycycline, trimethoprim/sulfamethoxazole and vancomycin. Meanwhile, we found it susceptible to amoxicillin, imipenem and ciprofloxacin.

Our patient subsequently received a three-week course of intravenous ciprofloxacin, amikacin, and trimethoprim-sulfamethoxazole. One month later, his leukocyte count decreased to $6.4 \times 10^{9} / \mathrm{L}(50 \% \mathrm{PMNs})$, the culture was found negative, and our patient was declared clinically cured. During a follow-up examination after one year, $N$. farcinica was cultured four, six and nine months later and was not cultured at two and three months and one year later.
In December 2007, our patient was started on a six-month course of trimethoprim and sulfamethoxazole (160/800 mg, 1.5 tablets, b.i.d.) and nebulized amikacin (500 mg, b.i.d., one month/two during six months) in order to eradicate the bacterium. However, because of the difficulty in isolating Nocardia species in sputum samples, as well as the poor sensitivity of the culture method, we decided to investigate retrospectively all sputum samples available for our patient using a more sensitive assay (molecular detection). For this purpose we used a specific putative non-ribosomal peptide synthetase sequence $[4,5]$ to develop an original real-time PCR assay with 
Taqman* probe. The primers designed for this RT PCR were as follows: NFF1 (5'-ACCGATCCGCCGT CAAATC-3') and NFR1 (5'-TCGGTCGTCCGGTG TGGA-3') that amplified a 147 bp of this gene with a probe of NFP1 (5'-CACATACCCCAACGCCAGC TGA-3'). The DNA from his sputa was extracted in a MagNa Pure LC instrument (Roche Diagnostics $\mathrm{GmbH}$, Mannheim, Germany) according to the manufacturer's instruction.

Using our PCR assay, all investigated negative and positive $N$. farcinica culture sputa were positive in PCR even in sputa recovered one year before the first culture detection (Figure 2). Retrospectively, our patient's medical record was rechecked as his clinical condition, including cough, haemoptysis, purulent mucoid expectoration, and elevated CRP and leukocytes (> 80\% PMNs) worsened at that stage.

\section{Discussion}

N. farcinica is a Gram-positive branching filamentous bacillus causing many localized and disseminated infections in humans, including pulmonary and wound infections, brain abscesses, and bacteremia [6]. Immunocompromised hosts and patients undergoing immunosuppressive therapies are more commonly affected by this bacterium [6], but the isolation of $N$. farcinica from the respiratory tract of patients with CF is rare. Only three reports described the isolation of this bacillus in patients with CF: the case of a 31-year-old woman with deteriorated clinical parameters [7], the case of an 8 -year-old boy who presented with fever and worsened chronic cough and who had previously received corticosteroid for allergic bronchopulmonary aspergillosis treatment [8], and the case of a 28-year-old woman with cough, dyspnea, fever, and hemoptysis and who had previously received corticosteroid [9]. Interestingly, our patient had a corticosteroid treatment history before the Nocardia isolation. Meanwhile, other Nocardia species have been reported in patients with CF, including $N$. asteroides, $N$. asiatica, $N$. elegans, and $N$. transvalensis $[9,10]$.

Nocardiae are ubiquitous in the environment and can be found worldwide in fresh and salt water, in a variety of soil types, dust, decaying vegetation, and decaying fecal deposits from animals [6]. Dasgupta et al. described a patient who was an active gardener [7]. Interestingly, our patient also worked as a gardener, which led us to conclude that he might have acquired the infection in his job.

The first isolation of $N$. farcinica in our case was associated with clinical symptoms including fever, haemoptysis, bronchial syndrome, and multiple bilateral bronchial thickening and radiographic change. Our patient was then chronically colonized with this bacillus

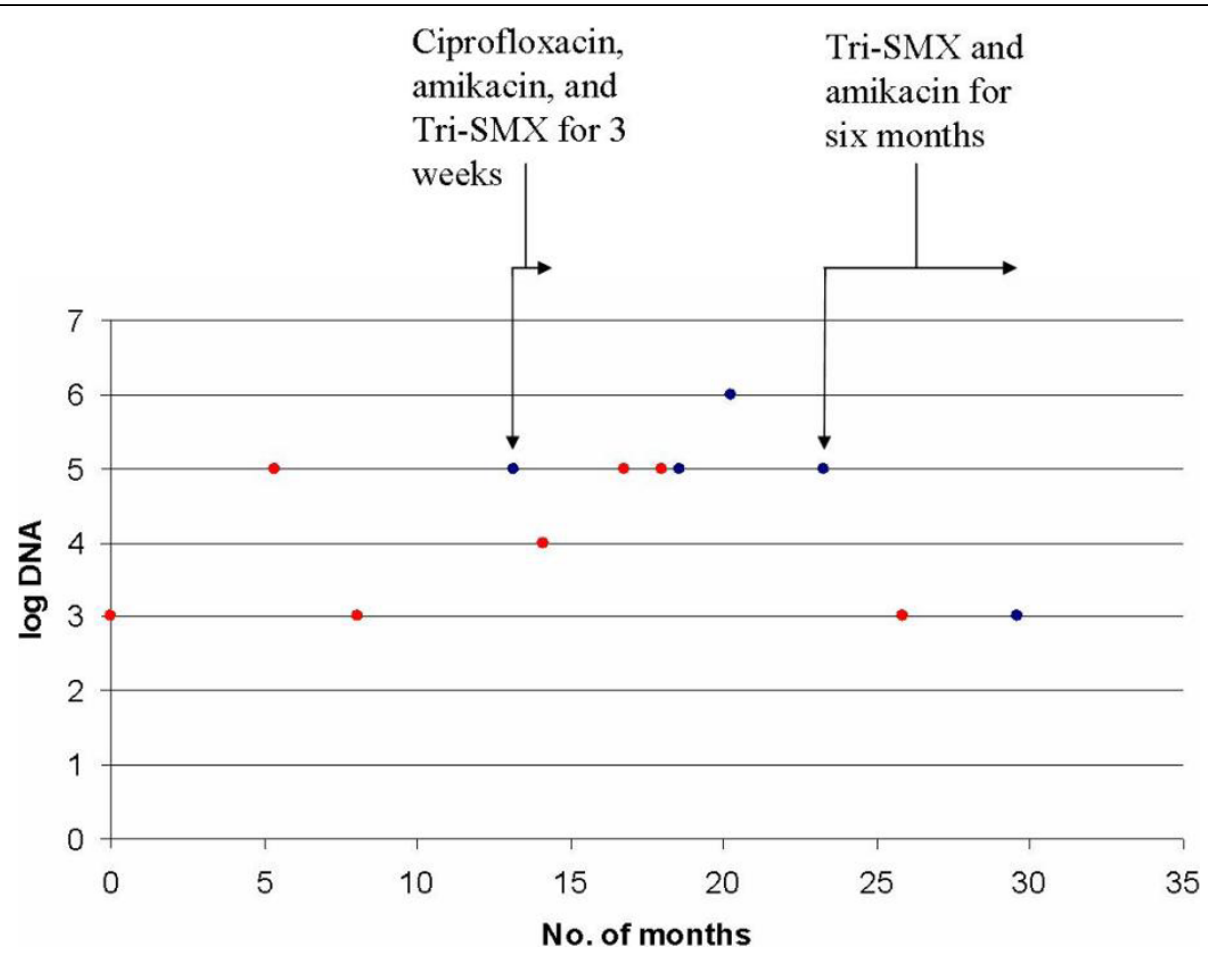

Figure 2 Nocardia farcinica DNA detection in different sputa recovered from the patient according the number of months and antibiotic treatment. Month $0=$ January, 2006. Blue point $=$ Nocardia farcinica positive culture. Tri-SMX $=$ trimethoprim-sulfamethoxazole. 
as proven by our new real-time PCR that appears more sensitive than culture (Figure 2). In the case reports of Isabel Barrio et al., [9], six of 9 patients (67\%) with Nocardia species isolations had clinical manifestations, while the Nocardia species were repeatedly isolated 3 patients. After a mean follow-up at $48 \pm 33$ months, however, the cultures were negative for all of the patients studied.

$N$. farcinica infections are potentially life-threatening $[6,11]$. The complete genome sequence of a clinical isolate (N. farcinica IFM 10152) revealed the presence of many candidate genes for virulence and antibiotic resistance [5]. After conducting a genomic analysis, the authors suggested that this bacterium can survive not only in soil environment but also in animal tissues, thus resulting in human disease [5]. It is now known $N$. farcinica is a multidrug-resistant bacterium that is susceptible mainly to amikacin, imipenem, trimethoprim/sulfamethoxazole, and ciprofloxacin [6]. Isolates from our patient were resistant to trimethoprim/ sulfamethoxazole.

Cases involving $N$. farcinica that is resistant to trimethoprim/sulfamethoxazole have been described previously $[5,12]$. Chronic lung colonization in our patient, which was demonstrated by his positive PCR assay, indicates that antibiotic treatment does efficiently and completely eradicate the bacterium. In two recent case reports, the authors indicate that the need for Nocardia treatment should be evaluated on an individual basis and in the context of a clinical picture $[9,10]$. We believe that Nocardia eradication is needed in patients with CF, especially if they are due to undergo lung transplantation. The reason for this is that the immunosuppressive regimen during the pre- and/or post-operative period is a wellestablished risk factor for serious cases of nocardiosis and disseminated disease that leads to high rate of mortality [13].

The impact of the presence of multiresistant pathogens on the survival of patients with $\mathrm{CF}$ after lung transplantation remains controversial $[14,15]$. In the case of nocardiosis in patients with CF, no recommendations or data appear in the literature.

\section{Conclusion}

We reported a case of lung infection followed by chronic colonization of trimethoprim-sulfamethoxazole resistant $N$. farcinica in a patient with CF. Our case report confirms that this infrequent organism can be recovered in such a population. We think that this unusual bacterium could be the cause of major clinical concern for patients with CF when immunosuppressive treatment is needed in cases requiring lung transplantation.

\section{Consent}

Written informed consent was obtained from the patient for publication of this case report and any accompanying images. A copy of the written consent is available for review by the Editor-in-Chief of this journal.

\section{Abbreviations}

CF: cystic fibrosis; CNA: Columbia colistin-nalidixic acid; CRP: C-reactive protein; PMNs: polymorphonuclear cells.

\section{Author details}

'Unité de Recherche sur les Maladies Infectieuses et Tropicales Emergentes (URMITE), CNRS-IRD, UMR 6236, Faculté de Médecine et de Pharmacie, Université de la Méditerranée, Boulevard Jean Moulin, 13385 Marseille cedex 5, France. ${ }^{2}$ Département des Maladies Respiratoires, Centre de Ressources et de Compétences pour la Mucoviscidose (CRCM), Hôpital Timone, Marseille, France. ${ }^{3}$ Laboratoire de Bactériologie, Centre Hospitalier, Boulevard des Rayettes, 13698 Martigues CEDEX, France.

\section{Authors' contributions}

FB collected the data and drafted the manuscript. NS, JPA, JCD and JS took care of our patient during his hospitalization. DR and JMR participated in the design and critical revision of the study and helped draft the manuscript. All authors read and approved the final manuscript.

\section{Competing interests}

The authors declare that they have no competing interests.

Received: 4 November 2009 Accepted: 8 March 2010 Published: 8 March 2010

\section{References}

1. Saiman L, Siegel J: Infection control in cystic fibrosis. Clin Microbiol Rev 2004, 17:57-71.

2. Lyczak JB, Cannon CL, Pier GB: Lung infections associated with cystic fibrosis. Clin Microbiol Rev 2002, 15:194-222.

3. Weisburg WG, Barns SM, Pelletier DA, Lane DJ: 165 ribosomal DNA amplification for phylogenetic study. J Bacteriol 1991, 173:697-703.

4. Brown JM, Pham KN, MCNeil MM, Lasker BA: Rapid identification of Nocardia farcinica clinical isolates by a PCR assay targeting a 314base-pair species-specific DNA fragment. J Clin Microbiol 2004, 42:3655-3660

5. Ishikawa J, Yamashita A, Mikami Y, Hoshino Y, Kurita H, Hotta K, Shiba T, Hattori M: The complete genomic sequence of Nocardia farcinica IFM 10152. Proc Natl Acad Sci USA 2004, 101:14925-14930.

6. Brown-Elliott BA, Brown JM, Conville PS, Wallace RJ Jr: Clinical and laboratory features of the Nocardia spp. based on current molecular taxonomy. Clin Microbiol Rev 2006, 19:259-282.

7. Dasgupta B, Brown N, Rennie R, Sand C: Isolation of Nocardia farcinica from a cystic fibrosis patient [abstract].http://www.cacmid.ca/ abstracts_04/h5_04.htm.

8. Petersen BE, Jenkins SG, Yuan S, Lamm C, Szporn AH: Nocardia farcinica isolated from bronchoalveolar lavage fluid of a child with cystic fibrosis. Pediatr Infect Dis J 2007, 26:858-859.

9. Barrio MI, Martinez MC, Prados C, Giron RM, Maiz L, Martinez MT: Isolation of Nocardia s pecies patients with cystic fibrosis. Arch Bronconeumol 2008, 44:109-112.

10. Lumb R, Greville H, Martin J, Sangster N, Holmes M: Nocardia asteroides isolated from three patients with cystic fibrosis. Eur $J$ Clin Microbiol Infect Dis 2002, 21:230-233.

11. De LI, Viejo G, Gomez B, De MD, Del VA, Otero L: Fatal pulmonary Nocardia farcinica infection. J Clin Microbiol 2002, 40:1098-1099.

12. Dodds EM, Echandi LV, Puente SI, Kaufman S: Subretinal abscess due to Nocardia farcinica resistant to trimethoprim-sulfamethoxazole in a patient with systemic lupus erythematosus. Ocul Immunol Inflamm 2006, 14:249-251.

13. Peleg AY, Husain S, Qureshi ZA, Silveira FP, Sarumi M, Shutt KA, Kwak EJ, Paterson DL: Risk factors, clinical characteristics, and outcome of 
Nocardia infection in organ transplant recipients: a matched casecontrol study. Clin Infect Dis 2007, 44:1307-1314.

14. Meachery G, De Soyza A, Nicholson A, Parry G, Hasan A, Tocewicz K, Pillay T, Clark S, Lordan JL, Schueler S, Fisher AJ, Dark JH, Gould FK, Corris PA: Outcomes of lung transplantation for cystic fibrosis in a large United Kingdom cohort. Thorax 2008, 63(8):668-670.

15. Peleg AY, Husain S, Qureshi ZA, Silveira FP, Sarumi M, Shutt KA, Kwak EJ Paterson DL: Survival of lung transplant patients with cystic fibrosis harboring panresistant bacteria other than Burkholderia cepacia, compared with patients harboring sensitive bacteria. J Heart Lung Transplant 2007, 26:834-838.

doi:10.1186/1752-1947-4-84

Cite this article as: Bittar et al:: Nocardia farcinica lung infection in a patient with cystic fibrosis: a case report. Journal of Medical Case Reports $20104: 84$

\section{Submit your next manuscript to BioMed Central} and take full advantage of:

- Convenient online submission

- Thorough peer review

- No space constraints or color figure charges

- Immediate publication on acceptance

- Inclusion in PubMed, CAS, Scopus and Google Scholar

- Research which is freely available for redistribution

Submit your manuscript at www.biomedcentral.com/submit 